\title{
The Rise of Illiberal Democracy and the Remedies of Multi-Level Constitutionalism
}

\author{
ANDRÁs LÁsZLÓ PAP* \\ ANNA ŚLEDZIŃSKA-SIMON**
}

\begin{abstract}
This article begins with a brief overview of the characteristics of illiberal democracy proclaimed in Hungary and followed by Poland, the once 'Musterkinder' of European integration and compliance with the EU values and law. In the second part the weaknesses of multi-level constitutionalism is analyzed by addressing the Hungarian and Polish illiberal turn. The third part consists of a country-specific contextual analysis examining remedies to illiberal democracy in a normative focus.
\end{abstract}

Keywords: illiberal democracy, constituton-making majority, NGO, Hungary, Poland

\section{ILLIBERAL DEMOCRACY IN HUNGARY AND POLAND}

'New Populism' is a core feature of illiberal democracy in Hungary and Poland, the once 'Musterkinder' of European integration and compliance with the EU values and law. This new populism flourishes in domestic cold wars that demonize political opponents and embrace the 'Zeitgeist' of disenchantment. In this climate, the sustainability of the postWWII (liberal) consensus on human rights and even certain democratic institutions is no longer secure. Although populism offers multiple operationalizing strategies both for rightand left-wing leaders in their contestation of the existing establishment, it is primarily used by neoconservative social movements against neoliberal policies and institutions designed to protect liberal values and individual rights. In effect, the traditional division between left and right is transformed into an ideological cleavage between populists and cosmopolitan liberals. ${ }^{1}$

The causes of this political climate change are growing economic inequality and instability, and a cultural backlash against modernity and progressive values. Paradoxically, illiberal populism is not grounded in any alternative political ideology to liberalism. Instead, it is driven by disappointment of the majority of active voters with the current political and economic elites and the global world order, including the uniforming influence of foreign powers - transnational corporations, the WTO or the EU.

In Central and Eastern Europe, illiberal democracy has become a discursive framework for building constitutional identity in opposition to multiculturalism, modernism, or even secularism. ${ }^{2}$ The term was coined by Viktor Orbán in a speech to Hungarian nationals living

* András László Pap: DSc., Research Chair, Hungarian Academy of Sciences, Centre for Social Sciences, Institute for Legal Studies, professor, National University of Public Service, papa@, ceu.hu. The research project was supported by the DEMOS - 'Democratic efficacy and the varieties of populism in Europe' H2020 RIA project, as well as the 129018 and 129245 Hungarian National Research and Innovation Grants.

** Anna Śledzińska-Simon: Assistant Professor, Chair of Constitutional Law, University of Wroclaw, anna.sledzinska-simon@uwr.edu.pl.

${ }^{1}$ Inglehart and Norris (2016).

2 It could also be argued that constitutional identity has become a discursive framework for illiberal democracy since it is used by constitutional courts in Hungary and Poland to denote the distinctiveness of their respective constitutional orders in the EU. 
outside the borders of their nation-state. ${ }^{3}$ Orbán, a former liberal, is now a Messiah of illiberal democracy and presents this concept as a viable alternative to liberal democracy and market economy. His doctrine is currently supported by a state-funded (pseudo) NGO sector, alongside the existing racist and nationalist movements and exported abroad. Even though the concept of illiberal democracy is not officially endorsed in Poland, the current government has adopted most of Orbán's strategies to dismantle the liberal constitutional regime and has followed a path of anti-modernism, anti-cosmopolitanism, and antiEuropeanism.

Characteristically, 'New Populism' is not accompanied by new grand narratives such as Marxism, Socialism, Communism, Fascism, or Nazism. Rather, it is very similar to how Eric Hobsbawm saw nationalism in the $20^{\text {th }}$ century - it is a substitute, a placebo for disorientation, and a surrogate for integration in a disintegrating society, when society fails, the nation appears as an ultimate guarantee. ${ }^{4}$ Yet, despite many superficial analogies with the 1930s, new illiberal movements are actually quite different. Today, anti-Semitism does not, and cannot, include the political, economic, and legal project of discrimination, exclusion, deportation, and annihilation of Jews. Similarly, contemporary nationalism is equally hollow.

In Hungary, the discourse of restoring pre-WW1 borders remains at the level of symbolic rhetoric and actual revisionist policies are nowhere to be seen. In Poland, the ruling Law and Justice party proposes a version of 'modern nationalism' which promotes cooperation between sovereign nations in a Christian Europe. However, it also juggles national sentiments and reinvigorates the trauma of the WW2, calling for German reparations for damages caused to the civilian population. Most recently, the party leader, Jarosław Kaczyński, has talked about the moral right of the Polish nation to receive financial aid from the EU. He played the anti-German card at exactly at the same time as the EU was weighting sanctions against Poland for the systemic breach of the rule of law.

Both governments oppose a number of EU policies, in particular the refugee quota plan $^{5}$ but they do not intend to withdraw from the EU. It is, therefore, apparent that illiberal democracies in Europe formally recognize limitations of multi-level constitutionalism, but are selective in the realization of obligations stemming from international law, membership in the EU, or even domestic constitutions which they find contrary to the political interests of the parliamentary majority. Most importantly, at the level of rhetoric, populist governments use very subtle sabotaging techniques to signal their resistance to the dictate of foreign rules. ${ }^{6}$

3 Speech at the 25th Bálványos Summer Free University and Student Camp (2014) link 1.

${ }^{4}$ Hobsbawm (1992) 163-92.

5 See action brought by Hungary and Slovakia against the 2015 Council decision regarding the mandatory refugee quotas.

${ }^{6}$ The Hungarian government's reaction to the European Court of Human Rights decision on incarcerating asylum seekers in so-called transit zones (Illias and Ahmed v. Hungary, Appl. No. 47287/15) is remarkable as for the first time government politicians began suggesting that Hungary should simply suspend its adherence to the Convention for the Protection of Human Rights and Fundamental Freedoms. According to János Lázár, Orbán's first lieutenant and the cabinet minister, the government considers the verdict 'unacceptable and impossible to implement,' while the leader of Fidesz's parliamentary caucus, Lajos Kósa, said that 'if Strasbourg continues criticizing Hungary's migrant policies, we must relinquish our adherence to the treaty'. Yet, the government undertook some steps to formally implement this decision - paid the compensation and passed the general measures (amending laws). See link 2. 
Undoubtedly, the rise of illiberal democracy in CEE has its origin in unsolved problems of democratic transition and the institutionalization of legal protection of national values and the ethnic majority. ${ }^{7}$ In the past, both the Hungarian and Polish nations suffered sovereignty loss after relatively long periods of national prosperity and greatness. This historic legacy is used by populist leaders to justify policies aimed to defend the national interest, redefine the position of their respective states in the world, and in effect 'regain' national sovereignty and pride.

'To help Poland get up off her knees' was a motto of a successful campaign led by the Law and Justice party in the last parliamentary elections of 2015. Yet, the trajectory of the populist rise in Hungary and Poland has actually been quite different. In Hungary, Viktor Orbán is the Prime Minister and hence a politically and constitutionally accountable actor while Jarosław Kaczyński, the leader of the Law and Justice and de facto leader of the government does not hold any official position per se except a parliamentary seat as a MP in the Lower Chamber. This difference is relevant for assessing the prospects for holding the populist government accountable for the current political upheaval in a legal process which is nevertheless dependent on the motion of the parliamentary majority. ${ }^{8}$

In Hungary, Fidesz won their constitution-making majority in the Parliament in 2010 and subsequently adopted a new constitution. ${ }^{9}$ Although it was never part of the 2010

7 In his public appearances, Orbán utilizes a new, precisely tailored, well-targeted, and highly effective nationalist political rhetoric. In his 2014 Bálványos speech he explained that '[t]he political and intellectual program of 1848 proclaimed: we will not be a colony! The program and the desire of Hungarians in 2012 is: we will not be a colony! Hungary could not have stood against the pressure and dictates from abroad in the winter of 2011-2012 if it were not for those hundreds of thousands of people who stood up to show everyone that Hungarians will not live as foreigners dictate, will not give up their independence or their freedom, therefore they will not give up their constitution either, which they finally managed to draft after twenty years. Thank you all!' See link 3.

${ }^{8}$ In Poland an indictment against the President of the Republic requires a resolution of the National Assembly passed by a majority of at least two-thirds of the statutory number of members of the National Assembly, on the motion of at least 140 members of the Assembly (Article 145(2) of the Polish Constitution), while bringing a member of the Council of Ministers to account before the Tribunal of the State can be done by a resolution passed by the Sejm by a majority of three-fifths of the statutory number of Deputies, on the motion of the President of the Republic or 115 deputies (Article 156 (2) of the Polish Constitution). In contrast, deputies of the Sejm and the Senate are constitutionally accountable only for performing business activity involving benefits derived from the property of the State Treasury or local government (Article 107 of the Polish Constitution).

9 On 28 June 2010, upon the proposal of a Fidesz MP, Parliament repealed Article 24 (5) of the Constitution, which required a four-fifths majority of MPs to adopt the procedural rules of the preparation of a new Constitution. In this way, the governing coalition, having a two-thirds majority, eliminated the provision obliging it to cooperate with opposition parties while preparing the new Constitution. The Parliamentary Ad Hoc Committee Preparing the Constitution was established on the same day. 30 out of its 45 were members of the governing coalition. The committee prepared a concept paper, which in the end was only considered to be a working document, while the draft of a new constitution was prepared by Fidesz/Christian Democrat MP's and introduced to the Parliament on 14 March 2011. The new constitution, called the Fundamental Law, was adopted only with the votes of the Fidesz/Christian Democrats coalition on 18 April and entered into force on 1 January 2012. It has been the sole product of the governing political party and has been adopted by the governing majority without the support of any other political force. The text, widely criticized by national, European, and international NGOs and organizations, was adopted on the basis of a bill deliberated only for 35 days and passed exclusively by the votes of members of the ruling coalition. 
electoral campaign, Orbán's regime proudly proclaimed that the new constitution finally finishes Hungary's political transition and completes the de-communization process that was suspended in 1990. Hungary certainly followed a unique path in post-communist transitions. Unlike other post-communist states, during the first wave of democratization of the 'pacted' or 'post-sovereign' constitution making, the adoption of an interim constitution, which was designed as the first of a two-step process was never followed by the adoption of a new basic law after the first democratic elections. Notably, Orban played on the lack of the constitutional-making mandate of the roundtable talks in 2010 even though his party played a crucial role in the 1989 negotiations..

In contrast, the Law and Justice party in Poland does not have a supermajority capable of changing the constitution. However, it has already in effect done this by adopting laws in blatant disregard of the letter of the Supreme Law and insisting on constitutional interpretation, which is irreconcilable with the fundamental principles enshrined in the Constitution. The party also uses a rhetoric challenging the legitimacy of the 1997 Constitution and accuses the post-Communist political and economic elites of usurpation of power and seizure of reprivatizated property. Notably, they also plan to hold a national referendum adopting a new constitution, which is expected to entrench the power of their ruling majority.

What both regimes have in common is the use of law as a tool for political change and justifying this process with the protection of national interests. Yet, all legislative reforms that officially aim to improve the effectiveness of public authorities actually serve the political interest of the ruling majority and help its members or sympathizers to occupy relevant positions of authority and power. In particular, new rules regarding the appointment and removal power in the public media, the prosecution office, the civil service, and the judiciary have ensured that the government has control over these once independent institutions.

The summary effect of these changes could be compared to a revolution by law. While the defenders of the 'ancient regime' try to engage in a rational discourse, their opponents contest the very rules of a discourse. The public and, in the case of Hungary, an overwhelming majority of the private media ${ }^{10}$ has become a political voice of the government and parliamentary opposition is either blocked or ignored. Moreover, in both legislatures, major government reforms are proposed as private members' bills in parliament, which do not require public consultations and adopted with extraordinary speed in violation of existing parliamentary customs and rules concerning the legislative procedure. As a result, Hungary and Poland have turned into sham parliamentary democracies, where almost all checks and balances have been abolished and conditions for democratic deliberation and participation are limited.

Both the Hungarian and Polish populist governments consider a parliamentary majority to be the supreme source of authority. In this way, they contrast the concept of legal constitutionalism with their own version of political constitutionalism and grant the supreme

However, to create the delusion of popular support, the government launched so-called 'national consultation' by a questionnaire sent to all eligible Hungarian voters. They were asked to answer 13 questions concerning the draft. According to the government (as there were no transparent means to verify this), 12 per cent of voters returned it.

10 See link 4. 
position to the sovereign power of the parliament in opposition to the power of judges, who are deemed to be lacking in democratic legitimization. ${ }^{11}$ In Poland, Kaczyński announced a plan to put an end to 'juristocracy'12 both Orbán and Kaczyński did not decide to do away with constitutional justice altogether. Instead they 'packed' the constitutional courts with political loyalists.

In Hungary, there is not a single justice who has not been cherry-picked by the government ${ }^{13}$ and many have a proven record as Fidesz loyalists, whether as cabinet members or other government office holders. In Poland, the controversial laws amending the Act on the Constitutional Tribunal, which led to the constitutional crisis in 2016, have allowed the government to choose the majority of judges, including the Chief Justice. ${ }^{14}$ Hence, the constitutional courts in Hungary and Poland continue to review ordinary legislation but in most politically relevant cases, their position coincides with the interests of the ruling party. ${ }^{15}$

It could, therefore, be argued that constitutional courts in Hungary and Poland are simply yet another instrument for the government's political maneuvers and cannot be characterized as an independent branch of government. Although the Hungarian Constitutional Court has passed a few judgments annulling government projects, these decisions ought to be taken with a grain of salt. First, the politically loaded decisions e.g., the law on churches, ${ }^{16}$ critiqued by both the European Court of Human Rights and the Venice Commission, ${ }^{17}$ and the media laws ${ }^{18}$ were adopted at the time when there were still justices on the bench who were elected prior to 2010 and were not nominated by Fidesz. ${ }^{19}$ In some of these cases, when the constitutional court went against the legislative and

11 The essence of the government viewpoint regarding a representative democracy as an alternative to a constitutional democracy is presented in the Expert Report on issues regarding the Constitutional Tribunal (available in English at: link 5.

12 For the origin of the term see Hirschl (2004).

13 In Hungary the Parliament elects Constitutional Court justices for 15 years with a two-third majority.

14 See link 6.

15 In Hungary the recent cases where the overwhelmingly Fidesz-elected Constitutional Court actually struck down government initiatives, such as for example the law blocking the transparency of public spending of the Central Bank (headed by one of Orbán's most important ally) (CC decision 8/2016. (IV. 6.)), the ban on publishing faces of police officers in duty in the media (CC decision 17/2016. (X. 20.)) are less significant and sensitive from the constitutional and political point of view. See also judgment of the Polish Constitutional Tribunal of 16 March 2017, Case no Kp 1/17 (finding in a preventive review that the new law on public assemblies introducing the institution of cyclical assemblies complies with the Constitution).

${ }^{16}$ CC decisions, 45/2012, 6/2013. (III. 1.), but also see 23/2015. (VII. 7.), 3144/2015. (VII. 24.).

17 CDL-AD(2012)004; CDL-AD(2013)012; CDL-AD(2011)016.

18 CC decision 165/2011. (XII. 20.).

19 Before 2010 nomination to the Court required a consensus with the opposition. Also, in 2011, the number of justices was raised from 11 to 15 , and later their tenure also raised from 9 to 12 years, and the elimination of a 70 years age limit. Also, the Courts competence was curtailed by excluding a power to review budgets and tax laws that passed Parliament when the national debt was more than $50 \%$ of the GDP. See link 7. 
executive decisions, the same provisions were either blatantly reintroduced or 'overruled' by preemptive constitutional amendments. ${ }^{20}$

A test case for the Hungarian Constitutional Court concerns the infamous 'lex CEU' adopted in 2017 to shut down the prestigious private research university, founded by George Soros. ${ }^{21}$ The Constitutional Court may be the only means for the government to save face if it decides to give in to domestic and international, political and professional pressures. ${ }^{22}$ Notably, the Chief Justice personally assigned this case to himself and has postponed its deliberation until an appropriate time.

Veto powers could be used in some cases to prevent major backlashes to constitutionalism, Presidents who are close friends of populist leaders may not actually serve as guardians of the constitutional order. Yet, the Polish President recently took responsibility for defending the principles of separation of powers and judicial independence, as well as the presidential prerogative, despite the law granting discretionary powers over the judiciary to the Minister of Justice. ${ }^{23}$ Still, it is difficult to ascertain or verify whether these acts of political disloyalty and disobedience are caused by an independent professional stamina or are in fact outcomes of a coordinated political strategy. Since the two vetoes concerning the act on the Supreme Court and the National Council of Judiciary were passed in reaction to street protests, they could be additionally explained by the fundamental difference in the position of the President of the Republic given the mode of their election - direct in Poland and indirect in Hungary.

Both the Hungarian and Polish governments openly exhibit disregard for parliamentary and extra-parliamentary opposition, foreign and domestic experts and are reluctant to follow recommendations and decisions of European institutions. They nevertheless seek legitimization of government policies before the court of public opinion and provide seemingly legal justification of their actions. In a state governed by law, replacing the state governed by the rule of law, the government keeps up the appearances of legality - it does in fact apply the minimum procedural standards and relies on legal arguments. For example, in response to the massive waves of international and domestic protest and criticism in the CEU-case, the government's response was always 'in Hungary everyone, even Soros and those on his payroll have to obey the laws.'

Another government tactic, employed in Hungary and Poland, is to refer to foreign laws or isolated constitutional provisions, which nevertheless need to be considered in the light of institutional checks and balances, and the national legal context. Yet, it is often the case that the public at large lacks the ability and expertise to unmask government lies or

${ }^{20}$ For example in reaction to the Court's quashing of the tax on the severance pay received by civil servants forced to retire. Also, the Fourth Amendment to the new Constitution (the Fundamental Law) banned political advertising during election campaigns in any venue other than in the public broadcast media, which is controlled by the all-Fidesz media board. These restrictions had been previously declared unconstitutional by the Constitutional Court. Similarly, constitutional amendments overrode Court decisions finding the definition of marriage too restrictive and parts of the law on churches. Certain provisions of the 2011 electoral law on campaign finance were also found to be unconstitutional (CC decision 1/2013) - and were later taken up again verbatim and constitutionalized by the Fourth and Fifth Amendment. See link 8.

${ }^{21}$ See link 9.; Halmai (2017), link 16., Trencsényi, Rieber, Iordachi, and Hîncu (2017) 412-436.

22 See link 10.

23 Bojarski (2017), link 11. 
expose irrationality of government policy, while the reaction of independent media and legal experts often comes too late to counter the mystification of legality. ${ }^{24}$

Last but not least, the characteristic feature of illiberal democracy is also the model of individual and social life promoted by the government. ${ }^{25}$ It endorses life choices that are compatible with the Catholic ethics, traditional gender roles, and family values. These objectives coincide with the mission of the Catholic Church which at least in Poland is actively involved in political life and openly grants support to populist leaders in exchange for the preservation of its numerous privileges and status. To these aim, both the Polish and the Hungarian governments have forced controversial educational reforms, and taken control of several state-owned cultural institutions.

\section{WEAKNESSES OF MULTI-LEVEL CONSTITUTIONALISM}

The following part highlights the weaknesses of multi-level constitutionalism to withstand the illiberal populist juggernaut in Hungary and Poland. Here, multi-level constitutionalism is understood as limited national sovereignty by virtue of membership in the European Union and other international organizations rather than a shared constitutional space that no longer espouses a clear hierarchy of constitutional norms. ${ }^{26}$ In a multi-level constitutional world order there are various centers of law-making and interpretation that are mutually dependent and interrelated. ${ }^{27}$

The legal order of the EU both respects and effects international public law and national constitutional law, while international public law has laid the foundations for the creation of the EU as the supranational entity. What EU law and international law share as a common ground is the respect for the fundamental principles of rule of law, democracy, and human rights. Yet, neither is able to effectively respond to breaches of these fundamental principles because both the European Union and international law are based on trust, while illiberal populist government may not be trusted. As a consequence, breaches of EU law and obligations stemming from membership in international organizations also constitute a breach of trust and pose not only a legal dilemma but an ethical one. Therefore, the question is whether public law (or legal action) may be effective in remedying disloyalty and a betrayal of common values and objectives. ${ }^{28}$

In the EU, the rule of law defense mechanisms are triggered by a political action which either requires a prevailing majority or unanimity. ${ }^{29}$ Hence, they could turn ineffective in

24 Matczak (2017).

25 Pap (2015) 53-75.

26 See Ingolf (2009) 349-407.

27 See de Búrca and Weiler (2012).

28 The European Commission did not initiate the infringement procedure against Poland when the Polish government carried out the attack on the Constitutional Tribunal even though it could be considered as the breach of the rule of law enshrined in Article 2 of the EU Treaty. Instead the Commission launched a political dialogue with the Polish authorities and adopted two sets of recommendations within the new Framework for addressing systemic threats to the Rule of Law.

${ }^{29}$ Under Article 7 of the Treaty on European Union, on a reasoned proposal by one third of the Member States, by the European Parliament or by the European Commission, the Council, acting by a majority of four fifths of its members after obtaining the consent of the European Parliament, may determine that there is a clear risk of a serious breach by a Member State of the values referred to in Article 2. The European Council, acting by unanimity on a proposal by one third of the Member States or by the Commission and after obtaining the consent of the European Parliament, may 
the case of two member-states that decide to defend each other against the EU institutions. Furthermore, the use of the 'nuclear option', as contained in Article 7 TUE, is only possible in reaction to gross breaches of the rule of law, democracy, and human rights that have already taken place. ${ }^{30}$ The EU legal-political defense system does not entail preventive mechanisms that could effectively discourage populist governments from undertaking a course of actions that are incompatible with the fundamental principles upon which the EU is based.

The Hungarian and Polish examples further demonstrate that legal action initiated by the European Commission before the Court of Justice for infringement of treaty obligations is only partially effective. Hungarian and Polish governments did not entirely withdraw from their policies, even after the CJEU found them contrary to the EU law. For example, in case of the Hungarian law reducing the retirement age of judges the law was formally repealed following the intervention by the $\mathrm{CJEU}^{31}$ and a Constitutional Court decision, ${ }^{32}$ but many of the former judges were reintegrated into posts inferior to the ones that they had previously occupied. ${ }^{33}$

Most recently, in an absolutely unprecedented move, the Polish government openly refused to follow the CJEU interim decision ordering Poland to stop the mass-scale logging in the ancient part of the Białowieża forest, protected as a UNESCO Heritage site. ${ }^{34}$ According to the CJEU, the logging could cause a serious and irreparable damage to the forest, and could only be justified by a situation endangering public safety. In response, the Polish government stated that its actions were necessary to protect the 1.3 million of trees affected by bark beetle. Notably, the interim decision of the CJEU was preceded by the UNESCO decision on the Białowieża forest, urging the government 'to immediately halt all logging and wood extraction in old-growth forests, and to clarify third party reports about logging targeting species other than those affected by bark beetle, which cannot be justified as so-called sanitary cuttings. 35

Hence, what is lacking in the EU legal order is a mechanism authorizing a preventive action of non-political actors (representing the interest of the EU rather than member states such as the European Commission) combined with the power to suspend the distribution of EU funds. For the time being, such possibility exists only in case a member state does not comply with the economic convergence criteria, particularly in cases of excessive budgetary

determine the existence of such a serious and persistent breach. Thereafter, the Council, acting by a qualified majority, may decide to suspend certain rights deriving from the application of the Treaties to the Member State in question, including the voting rights of the representative of the government of that Member State in the Council. The Commission may also bring the matter before the Court of Justice of the European Union.

30 Closa, Kochenov and Weiler (2014).

31 Judgment of the Court (First Chamber) of 6 November 2012, European Commission v Hungary, ECLI:EU:C:2012:687.

${ }^{32} \mathrm{CC}$ decision 33/2012. (VII.17).

33 See link 8.

34 Decision of 27 July 2017, Case 441/17 Commission v Poland.

35 Decision 41 COM 7b1, Krakow/UNESCO, 12 July 2017. 
deficits. ${ }^{36}$ Therefore, there is no connection between the political constitutional dimension and the economic constitutional dimension of the EU legal structure. ${ }^{37}$ The populist, illiberal turns in Hungary and Poland demonstrate a need to install a new compliance procedure focused on political criteria that would adopt the conditionality rationale of the preaccession process to the existing members.

In summary, the first weakness of multi-level constitutionalism concerns the institutional inability of the EU to restrain constitutional U-turns in its member states. Unlike the Council of Europe or the OSCE, the EU was not created as a human rights or a rule of law-watchdog organization - its primary goal was to foster economic cooperation and integration. For a long time, the EU democratic institutions were only relevant as far they were necessary to secure the EU's primary goals. A notable human rights area where the EU actually raised the standards for protection is the field of anti-discrimination law but this was not triggered by human rights considerations but by the fact that the equal treatment of workers and the free movement of services, goods, and capital were necessary to ensure the undisturbed functioning of the single market.

The second weakness of multi-level constitutionalism to address a democratic backlash concerns the EU's own constitutional design which is based on the principle of primacy of the EU law and also on the respect of constitutional identity of member states. According to the principle of primacy established by the European Court of Justice, ${ }^{38}$ the EU law is superior to laws of Member States, including their national constitutions and requires that national judges do not apply their national constitutions when in contradiction to the EU law. However, in the slow, organic and cautious development of the European project, the EU treaty law explicitly recognizes Member States' constitutional identity as sacrosanct ${ }^{39}$ as it is very wary of using any language that would create the impression of real federalism. ${ }^{40}$ According to Article 4(2) of the Treaty on European Union:

The Union shall respect the equality of Member States before the Treaties as well as their national identities, inherent in their fundamental structures, political and constitutional, inclusive of regional and local self-government.

36 See the procedure for suspension of European Structural and Investment Funds provided in Regulation (EU) No 1303/2013 of 17 December 2013 laying down common provisions on the European Regional Development Fund, the European Social Fund, the Cohesion Fund, the European Agricultural Fund for Rural Development and the European Maritime and Fisheries Fund and laying down general provisions on the European Regional Development Fund, the European Social Fund, the Cohesion Fund and the European Maritime and Fisheries Fund and repealing Council Regulation (EC) No 1083/2006

37 See Müller (2017a), link 14. and Müller (2017b), link 15.

38 The CJEU enshrined the precedence principle in the 1664 Costa versus Enel case (Case 6-64), declaring that the laws issued by European institutions are to be integrated into the legal systems of Member States, who are obliged to comply with them. European law therefore has precedence over national laws. Therefore, if a national rule is contrary to a European provision, Member States' authorities must apply the European provision. National law is neither rescinded nor repealed, but its binding force is suspended.

39 van der Schyff (2002) 563. See also Besselink (2010) 36. and 42.; von Bogdandy and Schill (2011) 1417. and 1430-31.

40 Consider for example the renaming of the 2003 Draft Treaty establishing a Constitution for Europe for a Charter of Fundamental Rights of the European Union (2007). 
This weakness thus refers to the EU's philosophy, which recognizes the constitutional diversity of member-states as an inherent element of its own constitutional structure. Yet, if a member state explicitly identifies itself as illiberal in its constitutional credo, there is little room for countering this democratic decline. ${ }^{41}$

The third weakness of both the EU and the Council of Europe, and within its structure the Venice Commission in particular, concerns their incapability to decipher legislative cynicism which builds upon elements that are not constitutionally suspicious. They pose no eminent breach of international human rights standards or contain solutions which would be unprecedented in well-functioning constitutional democracies. Yet, the grand picture generated by these mosaic pieces portrays a constitutional design in which institutional guarantees for government power are dismantled, the protection of fundamental rights is severely weakened, and political freedom is curtailed.

In this context, the use of constitutional comparativism fails as it would need to focus on this 'worst practice legislation.' In their legal analysis of reforms proposed by populist governments, international monitoring bodies seem to face a considerable difficulty in discovering the destructive features of the regime aside from the weakening of the existing constitutional guarantees. Sadly, even the most respected international authority such as the Venice Commission, is unable to raise specific, reasoned criticism that cannot be objected by a comparative argument pointing to examples of other countries where the contested institution or practice exists yet in a system where other checks and balances are intact. ${ }^{42}$

A case in point is the reaction of the European Commission to legislative reforms in Poland diminishing the effectiveness of constitutional review which is yet not a necessary institutional condition of the rule of law. ${ }^{43}$ What is indeed legally intriguing is the criterion of 'effectiveness' pointed out by Commission. It argued that '[w] here a constitutional justice system has been established, its effectiveness is a key component of the rule of law. ${ }^{44}$ However, there are in fact, no common normative standards of the effectiveness of constitutional review within the EU. The legal assessment of such effectiveness may vary and be subject to a wide scope of hypothetical argumentative scenarios. Therefore, at this point, the Commission's early concerns in relation to the rule of law in Poland address violations of the currently binding Polish Constitution rather than the assessment of the effectiveness of a given model of constitutional review. ${ }^{45}$

The tactic of the Hungarian government relying on comparative law builds what Kim Lane Scheppele called a 'Frankenstate'. She rightly observed that ' $[\mathrm{t}]$ he Fidesz constitutional 'reform' has spawned a Frankenstate, a form of government created by stitching together perfectly normal rules from the laws of various EU members into a monstrous new whole. The component pieces of the Hungarian Frankenstate might have operated perfectly well in their original contexts, but combined in a new constitutional system, these once-normal rules produce abnormal results. As government spokespeople have said every time there is criticism of a particular aspect of the new constitutional order: that rule exists in Greece.

41 See for example Halmai (2017), link 16.

42 Consider for example Orbán's most recent Putin-type attack on NGOs, which was found to be following a legitimate aim. CDL-PI(2017)002-e Hungary - Preliminary Opinion on the Draft Law on the Transparency of Organisations receiving support from abroad.

${ }^{43}$ See the argument used by the European Commission in its opinion on the legislative reforms concerning the Constitutional Tribunal in the Commission Recommendation regarding the Rule of Law in Poland, Com(2016) 5703 final, 27 July 2016.

${ }_{44} \mathrm{Com}(2016) 5703$ final, para. 85.

45 Mrozek and Śledzińska-Simon (2017). 
Or Germany. Or the United Kingdom. It's normal. End of story. But nowhere do all those rules exist together, except in the Hungarian Frankenstate. ${ }^{46}$

Lastly, domestic checks and balance mechanisms are unable to halt populist leaders once they 'neutralize' constitutional courts, cleanse public institutions from their political opponents, and recruit politically loyal persons to hold key public offices. All these changes aim to ensure political control of various institutions through the power of appointment and removal rather than introduce actual reforms increasing the efficiency of public administration and satisfaction of its clients. The numerical advantage of the ruling majority in the Parliament makes it virtually unstoppable in ordinary legislation, particularly if the President were not to use their veto power against the party, given the President's reliance on the the party's political support for gaining power.

While many of the adopted laws in Poland were actually in breach of the currently binding Constitution, the initiation of the constitutional liability proceedings before the Tribunal of the State is not a viable option as it requires the approval of the parliamentary majority. Hence, it is a remedy that could only be used after the populist government loses power and a new Parliament is able to build a coalition willing to put the President of the Republic, the Prime Minister or the government ministers to a trial.

In Hungary, the government could even afford to lose supermajority once its political preferences were cemented into law. The Venice Commission's warnings on the wide use of cardinal laws, voiced as early as 2011, proved right. The second report on Hungary pointed out that the Constitution contains far too many - over 50 - references to cardinal laws, most of which concern issues that ought to have been left to ordinary legislation and majoritarian politics, such as family legislation or social and taxation policy. ${ }^{47}$ The proliferation of cardinal laws was also accompanied by the extension of the mandates of several crucial public offices:

- the public prosecutor (9 years),

- the head of the state audit office (12 years),

- the head of the national judicial office ( 9 years),

- the head of the media board (9 years)

- the head of the budget council (6 years).

If a two-thirds consensus is not achieved in future parliaments, each office-holder could even be allowed to stay in post for even longer, thereby cementing clientelist loyalists into power for the future should the government loses its two-third majority.

${ }^{46}$ More specifically, in this analysis Scheppele brings the example of combining Germany's much-criticized rules for drawing electoral districts with Britain's highly disproportionate first-pastthe-post rules for constituency elections, and topping it off with the widely used d'Hondt system for deriving proportional representation from party-list votes, a system that marginalizes small parties. See Scheppele (2013).

47 Opinion No CDL(2011)016, of the European Commission for Democracy through Law (Venice Commission) on the new Hungarian constitution and the three legal questions arising out of the process of drafting the new Hungarian constitution. It stated that ' $[t]$ he more policy issues are transferred beyond the powers of simple majority, the less significance will future elections have and the more possibilities does a two-third majority have of cementing its political preferences and the country's legal order (...) When not only the fundamental principles but also very specific and 'detailed rules' on certain issues will be enacted in cardinal laws, the principle of democracy itself is at risk.' (para 22-25). 


\section{POLITICAL APATHY AND AD HOC POLITICAL ENGAGEMENT}

The following part explains the strength of illiberal populism in the context of national political circumstances. While in Hungary the success of Fidesz is partly a consequence of a political apathy and partly of a significant politicization of society, in Poland the victory of the Law and Justice party could be linked with a growing cleavage between the former political elite and the society, and ironically, a relatively high level of well-being.

According to a recent analysis, across Europe, populist parties retain the strongest support in Hungary. ${ }^{48}$ Value surveys portray Hungarians as passive, disinterested in politics, isolated, and distrustful, with an especially low trust in democracy, market economy, and transparent, merit-based structures. In 2012, only 40 per cent of Hungarian youth (mostly college and university students) accepted democracy as a legitimate system of government, and roughly one third did not see a difference between dictatorship and democracy. ${ }^{49}$

According to another survey, only about 20 per cent of respondents were interested in politics. ${ }^{50}$ In 2015, 58 per cent found little interest in politics, and 41 per cent reported no interest in solving social problems. ${ }^{51}$ While in 1991, 74 per cent of Hungarians approved of the change from a one-party system to a multiparty system, by 2009 only 56 per cent favored the change, and 77 per cent were dissatisfied with the way democracy was working in Hungary, which was the highest percentage of dissatisfied respondents in the region. While 89 per cent held that politicians have benefited a great deal from the changes since 1989 , only 17 per cent believed ordinary people have done so. 76 per cent said that corrupt political leaders are a very big problem. ${ }^{52}$ Only 38 per cent believed that voting is a mechanism for affecting politics, and 91 per cent thought the country is on the wrong track..$^{53}$

In contrast, Poles seem to be much more interested in politics, and according to the recent polls they currently declare the highest voter turnout (68 per cent) since the first democratic parliamentary elections after the fall of Communism in 1989 (62,7 per cent). ${ }^{54}$ Although in July 2017, more than half of the adult population was critical of the government, and since 2016 there is a stable tendency of decreasing identification of young people (between 18 and 24) with the political right, ${ }^{55}$ the political support for the ruling party is record high (40 per cent), and in the countryside, among less educated voters, it exceeds 50 per cent. ${ }^{56}$ It is noteworthy that the popularity of the ruling party has been not diminished after its attack on judicial independence. Evidently, the results of recent polls indicate that Polish citizens are more satisfied with their level of well-being and the generous social distribution policies rather than being worried about authoritarian inclinations of the government ministers.

In general, Poles are a much happier nation than Hungarians. According to the World Happiness Report, Poland ranks 46th in the happiness index, while Hungary is $75^{\text {th }}$, below

48 Boros and Kadlót (2016).

49 Szabó (2013).

50 Szabó (2013) 22.

51 Til (2015) 367-84.

52 Wike (2010), link 17.

53 Pew Research Center (2009), link 18.

54 Opinion poll on the willingness to take part in elections and interest in politics, CBOS 101/2017, August 2017.

55 Opinion poll on the right-wing identification of the youth, CBOS No. 102/2017, August 2017.

56 See opinion poll by IPSOS for independent media (2017), link 19. 
the Phillipines, Serbia, and Jordan. ${ }^{57}$ Remarkably, both countries score very low in social trust measured by a perceived absence of corruption in government and business, but Poles (0.059) are more trusting than Hungarians (0.037). Other data also shows that Hungary comes in at the very last of all European countries, including the former socialist states, in its levels of trust in institutions. ${ }^{58}$

It is apparent then that in Hungary the new political regime resonates with the expectations of a disillusioned, frustrated, inward-looking, closed Hungarian society that has lost its comparative advantage enjoyed during the time of relative freedom and economic prosperity created by the 'Goulash communism' of the pre-transition 1980s. ${ }^{59}$ Paradoxically, Hungarian society retains a sense of superiority, especially towards its neighbors with a significant ethnic Hungarian diaspora traditionally looked down upon by the dominant (self-referenced) 'Magyars.' Still, Hungarians have severely lacked feelings of success in the two decades since the political transition.

It also needs to be added that the conservative political ideology still centers around 1920 when in the post-WWI treaty Hungary lost two-thirds of its territory and the corresponding population, most of which were not ethnic Hungarian but there were homogenous Hungarian cities and territories. Ever since, the aspiration to reunite the old glory and territorial integrity, or later, the responsibility for ethnic kins in the neighboring countries, has been the cornerstone of conservative domestic politics and after the political transition in 1989, a constitutional responsibility and a foreign policy priority. The 1920 Treaty of Trianon also serves as a symbol of Hungary's and Hungarians' victimization and mistreatment by the international community. ${ }^{60}$ The narratives of victimhood allow for the culture of frustration and refusing responsibility for one's own fate and allowing others to be blamed for failures and the lack of success.

Similarly, the ruling majority in Poland is using criminal law to account for a broader question of transitional justice. In particular, the law criminalizing defamation of the Polish Nation could be viewed as a symptom of frustration, anxiety, and defensiveness of those who wish to present Poland as a victim of foreign powers. Although the narrative of victimhood may be effective in instilling the feeling of national identity in a new constitutional regime, it is definitely problematic when the protection of this image becomes a legislative aim justifying limitations of free speech and academic research. ${ }^{61}$

A contradictory feature of Hungarian politics lies in the fact that, despite a significant proportion of the population being in a state of political apathy and disinterest in public affairs, society is nonetheless highly politicized. Polarizing strategies aimed at demonizing and delegitimizing political opponents, initiated and utilized mostly by the right and foremost by Orbán and his party, have set the tone in political debates for over a decade.

57 Helliwell, Layard and Sachs (2017), link 20.

58 See Keller (2010), Szabó (2013); Wike (2010), link 17.; Pew Research Center (2009), link 18.

59 The term 'Goulash communism' evokes images of a community-style dish cooked in the open air to symbolize a communist regime with a relatively pleasant overall atmosphere. This term characterizes the mixing of certain elements of the free market with a planned economy that allowed Hungary to have had slightly higher living standards than its Iron Curtain neighbors and to be among the rare countries in the Eastern Bloc that did not have a shortage of food. See Wike (2010), link 17.

${ }^{60}$ Shortly after the elections, in 2010, parliament passed a law declaring June 4, the 90th anniversary of the Trianon Peace Treaty, a national day of remembrance (Act XLV of 2010).

61 Gliszczyńska-Grabias and Śledzińska-Simon (forthcoming). 
As Krasztev shows, private political preferences were transformed to identity issues, widely represented by a variety of commonly displayed symbols of self-definition against those with different political views. ${ }^{62}$ As a consequence, families, friendship circles and workplace networks have been fractured because of this sophisticated power trick. ${ }^{63}$

Thus, it is a defining feature of the illiberal democracy that instead of attempting to form and change society and culture, as Adenauer and Thatcher did, the government deliberately builds on the dark side of human nature. In Hungary, all of the nation's problems are blamed on hostile cooperation of foreign interests and a general disenchantment from democracy and the free market. ${ }^{64}$ In Poland, Jarosław Kaczyński invented a theory of a bomb attack plotted by the former government led by Donald Tusk in collaboration with Russia that killed his twin brother, Lech Kaczyński, then the President of the Republic. Both Orbán and Kaczyński have adopted these strategies for maintaining influence centered around polarization, division, and conflict. After losing the 2002 elections, Orbán initiated a political discourse centered on the phrase 'the nation cannot be in opposition.' Kaczyński coming to power after the electoral loss in 2007 started his political revenge against all real and potential enemies of the Polish nation - Communists, traitors, refugees, supporters of 'gender ideology,' calling those who do not support him 'people of a worse kind'.

In both cases the expropriation of the phenomenon of the 'nation' established a political environment that excludes any further compromise or cooperation, leading to a permanent crisis of governance. Both populist leaders created a political cold war, which actively deepened political and cultural divides. According to Rupnik, it is a transformation from 'transitology to traumatology' by not only breaking with the communist past, but also reconnecting with pre-communism by reopening old divides between cosmopolitan modernizers and traditionalist conservatives, "urbanists and populists, or 'Völkisch. ${ }^{\text {65 }}$ This orientation allows both governments to position Western liberal democracy as counter to true national values and identity.

In Poland, an important element of the national identity is Christianity. Building on a religious zeal, Kaczyński mobilizes the religiously devoted crowds around the cult of his brother and other victims of the Smolensk plane crash, portrayed as new martyrs. In order to commemorate this event without counterdemonstration, the government has amended the assembly law (which has been zealusly upheld by the Constitutional Tribunal in March 2017) and actively punishes those who break it, so that monthly remembrances on the tenth day of each month may go ahead undisturbed.

Yet, there is another important feature of Hungarian political culture which is absent in Poland. It is a phenomenon described by András Bozóki as 'partocracy,' or a case in which political parties assume civic duties and dominate public life. ${ }^{66}$ Such practices may be for, for example, establishing public benefit foundations, professional groups, club-like community forums called 'civic circles' (polgári kör), delegating curators to committees, employing their own journalists and political and market analysts, and self-administering most of the media outlets and think tanks. Additionally, the pervasiveness of party loyalist government organized non-governmental organizations (GONGOs) being masqueraded as

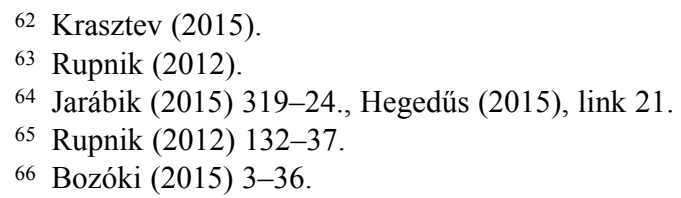


independent NGOs is remarkable. ${ }^{67}$ According to Jarábik, loyalty to political sides and parties is not a Hungarian specialty, yet nowhere else has the emerging civil society and the media been captured by the political parties to such a degree as in Hungary. ${ }^{68}$

On the contrary, the Polish constitutional crisis, and the government turn to illiberalism revealed immense social energy and initiatives which try to withstand some of the most outraging government decisions.

\subsection{Street Protests}

We argue that remedies to illiberalism should be sought at the ground level - in the People themselves. Given the above-mentioned weaknesses of multi-level constitutionalism in repairing the decays of representative democracy, remedies need to be found in civic society and public-political engagement of various groups through initiatives that raise social trust and confidence of the citizens in their own motive power. However, it is also evident that the resistance to populism is only possible once citizens feel that their individual interests are directly affected.

The Hungarian experience is quite confusing. In one case a massive demonstration led to the immediate withdrawal of a bill on taxing the internet. ${ }^{69}$ Likewise, an initiative for a referendum on the 2024 Olympic games ${ }^{70}$ led to a government retraction. However, other large protests (sometimes involving 100000 people in a country of 10 million inhabitants and 8 million voters) on education and health policies and the closing of down of Central European University ${ }^{71}$ have triggered no reaction on behalf of the government to reconsider its policies. In time, the waves of protest slowly faded away.

There are also two examples from Poland which proves that the concerted efforts of various civic organizations in voicing their disapproval of the government policy can bring the desired results. ${ }^{72}$ In the first case, on October 3, 2016, Polish women organized mass street protests (so-called 'Black Monday') that for the first time took place even in small towns. Inspired by a women's strike in Iceland in 1975 women wore black and stayed away from work. They were demonstrating against the bill introducing the almost total abortion ban. Eventually, the government withdrew its support of the law. ${ }^{73}$

Most recently, in a spontaneous reaction to the hastily adopted legislation regarding the Supreme Court, the National Council of the Judiciary, and ordinary courts, citizens' protests lasted several days. They were organized by a civic organization, Action Democracy, that insisted on their apolitical ('no logo') appearance. Although all opposition leaders were present at the demonstrations, the protest was oriented against these particular legislative acts and demanded three vetoes from the President. In effect, the President bound under this popular pressure, risking a deep conflict with the ruling party and the prospects for his reelections in case the party refuses to support his candidacy in 2020. Yet, the characteristic feature of this spontaneous movement was not its anti-government zeal but the disapproval of a specific set of legislative acts.

67 Kövér (2015) 81-90.

68 Jarábik (2015) 319-24.

69 See link 22.

70 See link 23.

71 See link 24.

72 Although several demonstrations in defence of the Constitutional Tribunal took place in December 2015 and in 2016, this movement has not been massive and the government continued to pass new obviously unconstitutional laws and refused to publish the Tribunal's judgements.

73 See link 25. 
Unlike, the first mass organization, the Democracy Defense Committee (Komitet Obrony Democracji), which was established after the Law and Justice party came into power in 2015 and conspired the political capture of the Constitutional Tribunal, these new civic movements are not turning political. Hence, the major question is how to transform $a d$ hoc political engagement of citizens into a political force capable to overthrow the populist governments in incoming elections. For the time being, neither in Hungary nor in Poland are such prospects clear.

\subsection{Mandatory Voting ${ }^{74}$}

As argued above, the contradictory feature of Hungarian and Polish politics lies in the fact that despite a significant proportion of the population being in a state of political apathy and disinterest in public affairs, the society is nonetheless highly politicized and divided. On this basis, it can be argued that mandatory voting could be a potential silver bullet to dethrone autocratic populists. ${ }^{75}$ This proposition uses the key argument of populist leaders who claim to have democratic legitimacy of the popular will. Yet, it is a fact that populist leaders owe their success to the large-scale disillusionment in most political parties by the majority of the electorate who do not take part in the elections.

In the Spring 2010 election, the joint list of Fidesz and the Christian Democratic People's Party (the Fidesz-KDNP list) received the support of 33.68 per cent of all voters in the electoral roll and $52.73 \%$ of the total votes cast for a party list. This election victory translated into $67.9 \%$ of seats in the Hungarian parliament, the National Assembly - a twothirds supermajority that allowed the government to amend the Constitution and organic laws. In contrast, in the 2014 election, the governing Fidesz-KDNP list was supported by $27.48 \%$ of the total electorate and by $44.87 \%$ of all voters who voted for a party list. However, a recent change in the electoral law allowed recently naturalized citizens, who were born and lived outside Hungary (mostly in ethnic Hungarian areas across the border) but could prove their Hungarian ancestry, to vote by mail, while Hungarian citizens who were born in Hungary proper but currently live and work abroad are not entitled to vote by mail and would have needed to appear in person to vote either at an embassy or a consulate (or at home, in Hungary). The Fidesz-KDNP list received the support of $95.49 \%$ of these newly-minted citizens who voted by mail, while their share of the votes among citizens who voted for a party list in Hungary or at Hungarian diplomatic missions abroad was $43.55 \%$. Thus, of the total electorate residing in Hungary proper only $26.61 \%$ voted for Fidesz. This significantly reduced the share of voters compared to the proportion of those who had voted for the Fidesz-KDNP list in 2010, it was nevertheless enough for almost the same share of seats in parliament, $66.83 \%$ - just enough for a two-thirds majority; though they actually lost this shortly thereafter due to the resignation of one MP.

In Poland, in the 2015 Autumn elections, the Law and Justice received 18.6 per cent of all eligible votes and 37.5 per cent of the votes cast, which translated into 51 per cent of mandates in the Lower Chamber. According to a survey carried out for an independent media outlet, mandatory voting in Poland would significantly change the political scene. If the Polish elections were mandatory, one in five Poles (21 per cent) would cast an invalid

74 See link 26.

75 Mandatory voting is currently used and enforced in several states, including Argentina, Australia, Belgium, Brazil, Cyprus, Ecuador, Lichtenstein, Luxembourg, Peru, Singapore, Uruguay, and on the sub-national level in India, and Switzerland. While formally in force it is not enforced in some 15 more states, some of which are 'model' Western democracies. 
vote, while the remaining 79 per cent would vote in such a way that could stop the ruling party from gaining an independent majority in the Parliament. ${ }^{76}$

On this basis, we argue that, despite gerrymandering and clientelist electoral commissions, along a tightly supervised prosecutor's office, tax authorities and administrative bodies in charge of billboards, Orbán and Kaczyński would face (and actually accept) electoral defeat if the large number of generally disillusioned but politically fatigued and inactive voters were obliged to enter the polls. We are not naïve in terms of the actual endorsement of this (suicidal) measure by the governing illiberal parties but since these formations actually run on the ticket of 'populism', where democracy is understood in the narrow sense of giving governance to the (majority of the) people, such a campaign would be difficult to reject on the rhetorical level. Indeed, an independently initiated referendum could be a successful tool to introduce such an institution.

Illiberal democracies are outcomes of the failure of constitutional democracies to reinvigorate themselves, and also of the lack of a novel rejuvenation of the democratic process in the digital era. Hence, a conservative remedy is in place. The idea that elections are about choosing the most attractive candidate needs a fairly easily arguable adjustment to the need to select the least disgusting/unattractive one. Mandatory voting would also be a game-changer for the electoral campaign, to the degree that it could even counterbalance asymmetries caused by government controlled public media and distorted campaign finance structures.

Let us not forget, despite financial suffocation and often direct political intrusion on the media, the past few years brought in Hungary an incredible and unprecedented flourishing of independent, partly NGO-driven investigative journalism where political corruption and conflicts of interests have been uncovered and reported. Still, sadly, in most cases these revelations remained without much political consequences, albeit sometimes led to successful strategic litigation. It is thus high time to remind the large segments of Hungarian and Polish society who remain passive and disinterested in public affairs that democracy is not solely about personal liberty, freedom of movement and economic freedoms but is also about responsibility for common good, which requires civic engagement and culminates in the act of voting-and this could even reverse populist U-turns.

Of course, mandatory voting is not a panacea for the crisis a constitutional democracy is facing. ${ }^{77}$ It simply offers a potential tool to combat populist, and in most cases authoritarian populist parties and governments. Addressing the root-causes for disenchantment, this claims to be no more than a symptomatic treatment. While silent protest and frustration without doubt are among the causes of non-voting, we believe that the preponderance is of this is vastly overestimated, as in most cases non-voters are simply disinterested and lack any sort of (moral, intellectual or pragmatic) incentive. Furthermore, there are several nonaggressive means to channel frustration and protest in a mandatory voting scheme as well: conscientious and conscious invalid voting, including writing messages, drawing obscene images, etc.

We also believe that there would be several marginal benefits of mandatory voting: it would radically change the political campaign by not only extracting additional financial resources from the hegemonic populist governments which usually control public media and a dominant segment of private media, especially the ones that actually reach voters beyond the already critical urban intellectual middle-class, but also by broadening not only

76 See link 27.

77 See Malkopoulou (2009) and link 28. 
the scope, rationale (and rationality!) of political debates, but also in effect accentuating and empowering marginalized political opinions. We must remember that constitutional democracies strive just as much on civil society and the potential for new, emerging, alternative (civil) voices as institutional arrangements.

These perilous constructs of new authoritarian populisms can only be destabilized from within and the very legitimizing pillars - popular elections and referenda - are institutions that should not be allowed to be used as a camouflage, lacking actual fair and free choice in managed and hegemonic elections. Electoral regimes are already tainted by gerrymandering, biased schemes for suffrage, campaign finance, and captured media.

Based on the reasonable presumption that mainstream protest-parties and in particular far-right extremist parties have already been able to mobilize and saturate most of their potential supporters, we do not believe that they would gain significant further support. More importantly, our proposition had been triggered by the conviction that nothing can be worse than the current trend: a steady dismantling of constitutional democracy, disguised in popular democracy and a façade of constitutionalism. ${ }^{78}$

\section{CONCLUSIONS}

The case of illiberal democracy in Hungary and Poland clearly shows that the popular support of the government and party leaders does not fade away notwithstanding the pressure of international institutions and the threat of sanctions. While on the theoretical level the success of illiberal populism in the region may indicate the prevalence of political constitutionalism over legal constitutionalism, and the preference for conservative and communitarian values over the liberal worldview, in practice it signals the irresistible desire of the people for the elite change. Yet, whilst illiberal populism in Hungary and Poland thrives on internal tribal wars, national sentiments, and complexes, it actually utilizes institutions of legal constitutionalism such as constitutional courts and the rights discourse to legitimize its policies. In essence, both populist governments use the rhetoric of political constitutionalism and slogans of democratization to introduce their political loyalist in all state, state-owned, or state-controlled institutions of power and influence, and use law as a tool to entrench their position.

Given the evident weaknesses of multi-level constitutionalism to address illiberal turns, in this competition between legal and popular constitutionalism, the remedies should be sought at the ground level - among the people themselves. However, they require certain guarantees of freedom and capacity to act, which might be preemptively curtailed by the populist governments adopting laws on financing of the NGOs sector or media. Therefore, the response of multi-level constitutionalism should focus on strengthening the social capital and the legacy of dissident movements in CEE. In particular, the Polish example of mass street protests proves that even an apparently disinterested generation of millennials can show interest in public affairs and mobilize in defense of the fundamental principle of liberal constitutionalism such as the separation of powers and judicial independence.

78 For the American context, consider for example that in the last election Americans between the ages of 18 and 24 voted for Clinton over Trump in a landslide. Only 43 percent of citizens in that age group voted, however, while Americans over age 65 supported Trump - and 71 percent of them voted. Similarly, Americans in their 30s were more likely to support Clinton, and less likely to vote, than those in their 50s. In midterm elections a mere 17 percent of Americans between 18 and 24 voted in 2014, compared with 59 percent of seniors. See Leonhardt (2017). 
Yet, it remains uncertain how to transform this spontaneous civic energy and ad hoc mobilization into a political program to counterweight the populist governments. A modest solution could be mandatory voting. In a long-term perspective, an answer seems to be in finding a fair balance between legal constitutionalism that is centered on legal institutions with practices suggesting a more open and flexible constitutional design, characteristic for political constitutionalism, and real opportunities for civic engagement and participation, inherent in civic constitutionalism.

\section{LITERATURE}

Besselink, Leonard F.M., 'National and constitutional identity before and after Lisbon' (2010) 6 Utrecht Law Review 36-49.

Birch, Sarah, 'Full Participation: A Comparative Study of Compulsory Voting' (United Nations University Press 2009).

Boros, Tamás and Kadlót, Tibor, 'A populizmus helyzete az Európai Unióban. Populista trendek és témák 2016-ban' (The Status of Populism in the EU. Populist Trends and Topics in 2016) (Policy Solutions - Friedrich-Ebert-Stiftung 2016).

Bozóki, András, 'Broken Democracy, Predatory State, and Nationalist Populism' in Krasztev, Péter and Jon Van Til (eds.), The Hungarian Patient. Social Opposition to an Illiberal Democracy (CEU Press 2015) 3-36.

David Leonhardt, 'If Liberals Voted,' New York Times, June 20, 2017.

de Búrca, Gráinne and Weiler, Joseph (eds.), 'The Worlds of European Constitutionalism' (Cambridge 2012).

Gliszczyńska-Grabias, Aleksandra and Anna Śledzińska-Simon, 'Victimhood of a Nation as a Legaly Protected Value in Transitional States - Poland as a Case Study' (forthcoming).

Hirschl, Ran, Towards Juristocracy: The Origins and Consequences of the New Constitutionalism (HUP 2004).

Hobsbawm, Eric J., Nations and Nationalism Since 1780 Programme, Myth, Reality (Cambridge University Press 1992).

Inglehart, Roland and Norris, Pippa, 'Trump, Brexit, and the rise of Populism: economic have-nots and cultural backlash' Paper presented at the plenary panel "Legitimacy of political systems. System support for comparative perspective," (24th World Congress of the International Political Science Association, Poznan, July 24, 2016).

Jarábik, Balázs, 'From Belarus to Hungary: Lessons from a Traditionalist Revolution' in Krasztev, Péter and Jon Van Til (eds.), The Hungarian Patient. Social Opposition to an Illiberal Democracy (CEU Press 2015) 319-24.

Keller, Tamás, 'Hungary on the world values map' (2010) 20 Review of Sociology 27-51.

Kövér, Ágnes, 'Captured by State and Church: Civil Society in Democratic Hungary Populism' in Krasztev, Péter and Jon Van Til (eds.), The Hungarian Patient. Social Opposition to an Illiberal Democracy (CEU Press 2015) 81-90.

Krasztev, Péter, 'Social Responses to the "Hybridization" of the Political System: The Case of Hungary in the Central and Eastern European Context' in Krasztev, Péter and Jon Van Til (eds.), The Hungarian Patient. Social Opposition to an Illiberal Democracy (CEU Press 2015) 167-80.

Malkopoulou, Anthoula, 'The History of Compulsory Voting in Europe: Democracy's Duty?' (Routledge 2015).

Mrozek, Anna and Śledzińska-Simon, Anna, 'Sravnitel'nyy vzglyad na pol'skiy konstitutsionnyy krizis: legitimnost' konstitutsionnykh sudov i printsip verkhovenstva prava' (On the Legitimacy of Constitutional Courts and the Rule of Law in a Comparative View on the Polish Constitutional Crisis) (2017) 1 Sravnitel'noe konstitutsionnoe obozrenie 64-79.

Pap, András László, "Who Are "We, the People"? Biases and Preferences in the Hungarian Fundamental Law' in: Zsuzsanna Fejes, Fanni Mandák and Zoltán Szente (eds.), Challenges and Pitfalls in the Recent Hungarian Constitutional Development. Discussing the New Fundamental Law of Hungary (L'Harmattan 2015) 53-75.

Ingolf, Pernice,'The Treaty of Lisbon: Multilevel Constitutionalism in Action, 15 Columbia Journal of European Law 15 (2009), 349. 
Rupnik, Jacques, 'How Things Went Wrong' (2012) 23 Journal of Democracy 132-37.

Scheppele, Kim Lane, 'The Rule of Law and the Frankenstate: Why Governance Checklists Do Not Work' (2013) 26 Governance 559-62.

Szabó, Andrea (ed.), Political Orientations, Values and Activities of Hungarian University and College Students, Active Youth in Hungary Research Group. (Heinrich-Böll-Stiftung 2013).

Til, Jon Van, 'Democratic Resurgence in Hungary: Challenges to Oppositional Movement (An OpenEnded Conclusion)' in Krasztev, Péter and Jon Van Til (eds.), The Hungarian Patient. Social Opposition to an Illiberal Democracy (CEU Press 2015) 367-84.

Trencsényi, Balázs - Rieber, Alfred J. - Iordachi, Constantin - Hîncu Adela, 'Academic Freedom in Danger. Fact Files on the "CEU Affair"', Südosteuropa (2, 2017) 412-36.

van der Schyff, Gerhard, 'The Constitutional Relationship between the European Union and its Member States: The Role of National Identity in Article 4(2) TEU' (2002) 37 EL Rev 563-84. von Bogdandy, Armin and Schill, Stephan, 'Overcoming Absolute Primacy: Respect for National Identity under the Lisbon Treaty’ (2011) 48 CMLR 1417-54.

\section{LINKS}

1. 'Speech at the 25th Bálványos Summer Free University and Student Camp' 2014, <www. kormany.hu/hu/a-miniszterelnok/beszedek-publikaciok-interjuk/a-munkaalapu-allamkorszaka-kovetkezik> accessed 10 January 2019.

2. 'The Hungarian Government's Flouting of European Law and Human Rights' 2017, <http:// hungarianspectrum.org/2017/03/28/the-hungarian-governments-flouting-of-european-law-andhuman-rights/> accessed 10 January 2019.

3. 'Orbán calls 'ethnic homogeneity' a key to success' 2017, <https://www.euractiv.com/section/ justice-home-affairs/news/orban-calls-ethnic-homogeneity-a-key-to-success/> accessed 10 January 2019.

4. Átlátszó, 'Oligarchs and government control: Pressure on media mounts in V4 countries as the EU watches' 2017, <https://english.atlatszo.hu/2017/08/10/oligarchs-and-government-control-pressureon-media-mounts-in-v4-countries-as-the-eu-watches/> accessed 10 January 2019.

5. 'Expert Report on issues regarding the Constitutional Tribunal' 2016, <http://www. marekkuchcinski.pl/wp-content/uploads/2016/09/EN-Raport-Zespo\%C5\%82u-Ekspert $\% \mathrm{C} 3 \% \mathrm{~B} 3 \mathrm{w}$-do-spraw-problematyki-Trybuna\%C5\%82u-Konstytucyjnego-wersja-angielska1.pdf> accessed 10 January 2019.

6. Szuleka, Małgorzata, Szwed, Marcin, Wolny, Marcin, 'The Constitutional Crisis in Poland 2015-2016' 2016, <http://www.hfhr.pl/wp-content/uploads/2016/09/HFHR_The-constitutionalcrisis-in-Poland-2015-2016.pdf $>$ accessed 10 January 2019.

7. 'Hungary's Government Has Taken Control of the Constitutional Court', <http://www.helsinki.hu/ en/hungarys-government-has-taken-control-of-the-constitutional-court> accessed 10 January 2019.

8. FIDH, 'Hungary: Democracy under Threat Six Years of Attacks against the Rule of Law' November $2016 / \mathrm{N}^{\circ}$ 684a H, <https://www.fidh.org/IMG/pdf/hungary_democracy_under_threat. pdf $>$ accessed 10 January 2019.

9. 'CEU Welcomes European Parliament Call to Repeal Lex CEU; Calls Again for Negotiation' $<$ https://www.ceu.edu/article/2017-05-17/ceu-welcomes-european-parliament-call-repeal-lexceu-calls-again-negotiations $>$ accessed 10 January 2019.

10. Bayer, Lili, 'Hungarian president signs anti-Soros education law' 4 November 2017, $<$ http://www.politico.eu/article/hungarian-president-signs-anti-soros-education-law/> accessed 10 January 2019.

11. Bojarski, Łukasz, 'A Polish Legal Road Roller: Can a Political Sentence be Stopped?' 31 July 2017, <http://www.constitutionnet.org/news/polish-legal-road-roller-can-political-sentence-bestopped $>$ accessed 10 January 2019.

12. Matczak, Marcin, 'Who's next? On the Future of the Rule of Law in Poland, and why President Duda will not save it' 19 July $2017<$ http://verfassungsblog.de/whos-next-on-the-future-of-therule-of-law-in-poland-and-why-president-duda-will-not-save-it/> accessed 10 January 2019. 
13. Carlos Closa, Dimitry Kochenov, J.H.H. Weiler, Reinforcing Rule of Law Oversight in the European Union, EUI Working Paper RCCAS 2014/25, <http://cadmus.eui.eu/bitstream/ handle/1814/30117/RSCAS_2014_25_FINAL.pdf?sequence=3> accessed 10 January 2019.

14. Manuel Müller, 'Geld nur bei Wohlverhalten: Sind politische Bedingungen der EU-Strukturfonds die Lösung für Ungarn und Polen?," 31 May 2017, <http://www.foederalist.eu/2017/05/ kein-geld-regelbrecher-politische-bedingungen-eu-strukturfonds-ungarn-polen.html $>$ accessed 10 January 2019.

15. Manuel Müller, 'Rechtsstaat in Polen: Welche Optionen hat die EU?,' 25 July 2017, <http:// www.foederalist.eu/2017/07/rechtsstaat-polen-optionen-eu.html> accessed 10 January 2019.

16. Gábor Halmai: The Hungarian Constitutional Court and Constitutional Identity, 10 Jan 2017, $<$ http://verfassungsblog.de/the-hungarian-constitutional-court-and-constitutional-identity/> accessed 10 January 2019.

17. R. Wike, Hungary Dissatisfied with Democracy, but Not Its Ideals, 2010, <http://www.pewglobal. org/2010/04/07/hungary-dissatisfied-with-democracy-but-not-its-ideals/> accessed 10 January 2019.

18. Pew Research Center, End of Communism Cheered but Now with More Reservations, 2009, $<$ http://www.pewglobal.org/2009/11/02/end-of-communism-cheered-but-now-with-morereservations/> accessed 10 January 2019.

19. Opinion poll by IPSOS for independent media - OKO.press, 2-7 August 2017, <https://oko. press/pis-40-proc-najsilniejszy-wyborow-opozycja-najslabsza-zamach-sady-zaszkodzil-wladzy/> accessed 10 January 2019.

20. John Helliwell, Richard Layard and Jeffrey Sachs, World Happiness Report 2017, <http:// worldhappiness.report/> accessed 10 January 2019.

21. D. Hegedüs, 'From Front-runner's 'EUphoria' to Backmarker's 'Pragmatic Adhocism'?: Hungary's Ten Years within the European Union in a Visegrad Comparison," DGAPanalyse 2015, $<$ https://dgap.org/en/think-tank/publications/dgapanalysis/front-runners-euphoria-backmarkerspragmatic-adhocism $>$ accessed 10 January 2019.

22. Hungary internet tax cancelled after mass protests, <http://www.bbc.com/news/worldeurope-29846285> accessed 10 January 2019.

23. Hungary to withdraw Budapest's 2024 Olympic bid: government, <http://www.reuters.com/ article/us-olympics-2024-budapest-idUSKBN1610YO> accessed 10 January 2019.

24. Marton Dunai, 'Hungarian students march to parliament in protest at university law," $<$ http:// www.reuters.com/article/us-hungary-soros-university-idUSKBN17E0QC $>$ accessed 10 January 2019.

25. Viktoia Lindrea, 'Poland's parliament withdraws proposed abortion ban," 6 October 2016, CNN, $<$ http://edition.cnn.com/2016/10/06/europe/poland-abortion-ban-rejected/> accessed 10 January 2019.

26. Andras Pap and Anna Sledzinska-Simon, 'Mandatory Voting as a Tool to Combat the 'New Populism," <http://www.iconnectblog.com/2017/04/mandatory-voting-and-the-new-populism/> accessed 10 January 2019.

27. Opinion poll: higher voter turnout would deprive the Law and Justice party of the independent rule, <https://www.wprost.pl/kraj/10068433/Sondaz-Wyzsza-frekwencja-wwyborach-pozbawilaby-PiS-samodzielnych-rzadow.html> accessed 10 January 2019.

28. Waleed Aly, "Voting should be mandatory," 19 January 2017, <https://www.nytimes. com/2017/01/19/opinion/voting-should-be-mandatory.html> accessed 10 January 2019.

\section{OPEN ACCESS}

This is an open-access article distributed under the terms of the Creative Commons Attribution 4.0 International License (https://creativecommons.org/licenses/by/4.0), which permits unrestricted use, distribution, and reproduction in any medium, provided the original author and source are credited, a link to the CC License is provided, and changes - if any - are indicated. (SID_1) 